Branislav Živanović ${ }^{*}$

Filozofski fakultet

Univerzitet u Novom Sadu
UDK: 821.111.09-31 Barnes J.:82.09

821.521.09-32 Akutagava R.:82.09

DOI: $10.19090 / \mathrm{gff} .2021 .2 .99-113$

Originalni naučni rad

\title{
VIŠESTRUKA FOKALIZACIJA U PRIČI $U$ ČESTARU RJUNOSUKEA AKUTAGAVE I ROMANU TROJE DŽULIJANA BARNSA ${ }^{1}$
}

U radu ćemo se baviti pripovednim postupcima i analizom mnogostrukih suprotstavljenih perspektiva iz koje su predočeni događaji i situacije u priči $U$ čestaru japanskog pisca Rjunosukea Akutagava i romanu Troje britanskog pisca Džulijana Barnsa. Kako je u delu obojice autora pripovedni postupak uslovljen fokalnim tačkama, metodološki okvir rada baziran je na naratološkom pristupu i teorijskim radovima Žerara Ženeta o perspektivi i fokalizaciji. S obzirom da Ženet specifikuje mesto fokalizatora unutar priče/dijegeze insistiranjem na razlikovanju onoga ko vidi/opaža od onoga ko govori, pokazaćemo kako umesto jednog klasično/tradicionalno određenog centralnog pripovednog glasa, stepen pouzdanosti i istinitosti kazivanja u Akutagavinom i Barnsovom narativu zavisi od perspektive više likova kao centralnih glasova koji su ujedno nosioci radnje i pripovedanja.

Ključne reči: fokalizacija, perspektiva, Akutagava, Barns, pripovedanje, pripovedač, priča, narativ

Dobro izveden narativ zaokuplja pažnju mnoštvom priča koje se otvaraju ili nagoveštavaju čitanjem, a upotpunjuju utisak veštim smenjivanjem u osnovnom narativu. U pitanju su narativni rukavci koji se odvajaju od glavnog toka priče, međusobno prepliću stvarajući atmosferu neizvesnosti. Nadmetanje narativa može se pronaći u tekstovima koji prikazuju određenu situaciju ili događaj, fikcionalan ili nefikcionalan, a najčešće se može sretati u književnim delima baziranim na istražnom postupku, oponašanjem svedočenja više aktera pred sudom ili porotom. Takav narativ je priča $U$ čestaru japanskog modernističkog pisca Akutagave Rjunosukea (1892-1927), koja ne prestaje da izaziva različita tumačenja i predstavlja simbol nerazrešenog nadmetanja. Drugi primer, sa identičnom

\footnotetext{
*branislav.zivanovic@ ff.uns.ac.rs

${ }^{1}$ Skraćena verzija rada nastalog na doktorskim studijama iz predmeta Komparativne poetike pod mentorstvom prof. dr Bojane Stojanović Pantović, položen 16. 6. 2020. godine.
} 
narativnom postupkom, za potrebe relacione usporedbe pozajmljen iz postmodernističkog prosedea, predstavlja roman Troje savremenog engleskog pisca Džulijana Barnsa (1946).

Akutagavina priča i Barnsov roman za predmet imaju problem istine, odnosno njene relativnosti. Oba dela provociraju postavku Žerara Ženeta o spoljašnjoj fokalizaciji gde se specificira mesto fokalizatora (subjekt tačke gledišta) unutar dijegeze (primarna pripovest), ali izvan bilo kojeg od protagonista, insistiranjem na razlikovanju fokalizacije (ko vidi/opaža/razume) od glasa (ko govori/pripoveda) (v. Tipovi: 99-103 i Perspektiva 83-86). Dok je u priči U čestaru istina vezana za jedan događaj ispričan iz ugla onoga ko izgovara (učesnici i svedoci), u romanu Troje postoji više međusobno isprepletenih situacija i događaja, pa samim tim različitih vremenskih raspona koje junaci svojim pripovedanjem nastoje da predstave. Oba narativa u polifono organizovanoj strukturi književnih tekstova žanrovske i poetičke različitosti ukazuju na moguće multiplikovane subjektivnosti u vezi sa jednim određenim događajem ( $U$ čestaru) ili više događaja i situacija (Troje), proizvodeći na taj način različite istine u procesu narativnointerpretativne repetativnosti. Prema Volasu Martinu ,[a]ko priča sadrži više od jednog fokalizatora, promene od jednog do drugog postaju aspekt narativne strukture" (133), što odgovara trećoj koncepciji unutar Bartove strukturalne analize pripovedanja kao odašiljanja teksta koja „nalaže da pripovjedač ograniči svoj pripovjedni tekst na ono što mogu primijetiti ili znati likovi: sve se zbiva kao da svaki lik u svoje vrijeme odašilje pripovjednu poruku." (68-69).

Pored priče $U$ čestaru i priča Rašomon iz istoimene Akutagavine zbirke priča bavi se univerzalnim pitanjima vezanim za ljudsko stanje, koje će poslužiti japanskom režiseru Akiri Kurosavi da snimi dugometražni igrani film nagrađen „Oskarom“, Rašomon iz 1950. godine, Pozajmljujući filmu naslov Akutagavine zbirke priča, Kurosava je nastojao da ukaže na piščevu intenciju o drugačijoj perspektivi pri pogledu na jedan događaj ili stvar, tj. o relativnosti istine kojom se Akutagava bavi u nosećoj priči. Nazivan ocem japanske pripovetke, Akutagava Rjunosuke prepoznat je kao virtuoz kratke priče pisane sa znatnim udelom satiričnog elementa i modernističkim nasleđem koje uporište nalazi u japanskoj tradiciji narodnog stvaralaštva Konđaku monogatari (v. Akutagava 105-110). Smatra se najvažnijim piscima Tajšo perioda (1912-1926) (v. Kođiki 2008), u doba „kada naturalizam (kao inherentno mračan i pesimističan književni pravac unekoliko nevešto preslikan iz evropske književnosti) gubi primat najzastupljenijeg pravca u japanskoj književnosti““ (Marković 122). Irski teoretičar književnosti Patrik O'Konor stvaralaštvo Rjunosukea Akutagave dovodi u vezu sa proznim 
stvaralaštvom Edgara Alana Poa, zbog toga što ,zalazi u mračne uglove ljudske duše i stvara zapanjujuće, nezaboravne likove i situacije koje su odražavale ono što je u tim uglovima pronašao“ (79). Otud ne iznenađuje povremeni prodor fantastičnog u Akutagavinim pričama, poput intervencije duha ubijenog samuraja i njegove priče/ispovesti posredstvom figure medijuma ( $U$ čestaru). Prodor fantastičnog pravda se tradicionalnom japanskom književnošću - monogatari - na koju se, poput mnogih modernističkih i savremenih japanskih pisaca, oslanjao i Akutagava. $^{2}$

Tokom svog kratkog životnog veka Rjunosuke Akutagava napisao je preko sto pedeset priča i novela koje su prevedene na više svetskih jezika. Tematski raspon priča obuhvata pitanje religije, morala i nepravde $u$ društvu, dok je za junake iz druge faze pripovedanja pretežno reč o običnom, često siromašnom čoveku rastrzanom egzistencijalnim problemima i dilemama. Kako navodi Ljiljana Marković, period njegovog književnog stvaralštva beleži tri etape: prva do 1920. godine, druga od 1920. do 1923. godine, i treća od 1924. do smrti (124). Priča Rašomon (1915) pripada prvoj fazi Akutagavinog stvaralaštva, i u njoj Akutagava oslikava psihološku i moralnu stranu čovekove ličnosti govorom o trojici putnika koji se jedne večeri usled nevremena sreću u ruiniranom hramu Rašomon. Priča $U$ čestaru (1922) pripada drugoj etapi Akutagavinog stvaralaštva, gde pisac preispituje i kritikuje ljudske naravi, sebičnot i egoizam. Ova priča o otmici, silovanju i ubistvu, ispričana je kroz sedam različitih govornih lica, od kojih su tri akteri samog događaja, što se postupno konstruiše u dopunskom mozaičkom preplitanju sučeljenih narativa koji se međusobno nadopunjavaju i pobijaju. Sa stanovišta naratologije i teorije proze, možemo reći da se u ovoj Akutagavinoj priči suočavamo sa onim što se prema pojmovnom leksikonu Dorit Kon naziva diskordantnim naratorima (Abot 131), a što Vejn But u svojoj tipologiji pripovedača imenuje kao podrazumevan (implicitan) autor (177). U pitanju su

2 ,Žanr monogatari je izuzetno važna pojava u književnoj istoriji Japana. Monogatari je vrlo širok pojam i postoje različite teorije o tome koja se sve dela japanske književnosti njime mogu obuhvatiti. Shodno pristupima i termin monogatari se prevodi kao priča, pripovetka, novela ili roman. U najužem smislu ovaj žanr obuhvata dva podžanra Heian perioda. Prvo nastaju cukuri monogatari - prozni tekstovi fantastične sadržine. U njima su realni elementi prožeti fantastikom, a likovi su junaci karakteristični za bajke i predanja, ali i istorijske ličnosti. Drugi podžanr je uta monogatari - prozni tekst sa vaka pesmama (najzastupljenija tradicionalna poetska forma u Japanu, pesma od pet stihova sa metričkim rasporedom slogova 5-7-5-7-7, prim B.Ž.). Čine ga prozno-poetske forme književnih dela, u kojima poezija ne poseduje samo estetsku funkciju, već ima ključnu ulogu u razvoju sižejnog toka.“ (Vasić 94). 
pripovedači „na koje se možemo osloniti kad iznose činjenice, ali ne i kada ih tumače, jer je njihova interpretacija u suprotnosti sa pretpostavljenom interpretacijom autora" (Abot 131).

Dok se Kurosavin filmski narativ tek načelno drži sižea i atmosfere okvirne priče Rašomon, u određenim aspektima delimično odstupa od načina pripovedanja dominantne priče, $U$ čestaru. Naime, tokom nevremena i kišne oluje, drvoseča (Takaši Šimura), sveštenik (Minoru Ćiaki) i građanin (Kićiđuro Ueda) založiće vatru i sa čuđenjem slušati uznemirujuću priču koja će uslediti (U čestaru). Ukratko, ovaj uvod predstavlja priču-u-priči ili okvirnu priču glavnoj prči: o supružnicima i razbojniku koji ih susreće na šumskom putu, priči o otmici, silovanju i ubistvu. Dok kroz vizuru Tađomarua (Toširo Mifune) posmatramo put kroz čestar, gledalac postepeno otkriva perspektivu odmetnika. Ugledavši Masago (Maćiko Kjo), Tađomaru će je prisiliti da mu se preda pre nego što oslobodi njenog prethodno razoružanog i zarobljenog supruga samuraja, Takehira (Masajuki Mori). Za njenu naklonost dva muškarca će se boriti sve dok jedan od njih dvojice u tom dvoboju ne bude ubijen. Masako pripoveda da ju je suprug silovao i ponizio, a potom odbacio, te je zbog toga, u afektu, iz osvete, ona ta koja ga je ubila. Slažući se samo tim da je ubijen, Takehiro, koji se obraća posredstvom medijuma (Fumiko Homna), pripoveda o strasti Tađomarua koja je prethodila Masaginom zahtevu da Tađomaru nad njim počini ubistvo. Ne nalazeći razrešenje u ubistvu, Tađomaru i Masago beže ostavljajući obeščašćenog samuraja da počini sepuko. Priča o počinjenom zločinu ispričana je četiri puta. Najpre to čine učesnici događaja, a zatim svedok - drvoseča, koji pronalazi muževljev leš i svedoči pred policijskom komisijom koja istražuje šta se dogodilo. Opis dešavanja toliko će uznemiriti sveštenika a zabaviti građanina da će im četiri međusobno pobijajuća objašnjenja zločina okupirati pažnju tokom trajanja oluje, dok, didaktivnom metodom, budu pokušavali da odgonetnu istinu o onome što se zapravo dogodilo. U zavisnosti od ugla posmatranja, odnosno slušanja, tužilaštvo i odbrana su istovemeno antagonisti i protagonisti u ulozi autora sa namerom da svoje priče predstave verodostojno i uverljivo ne bi li zadobili poverenje publike.

S obzirom da predstavlja sintezu dveju priča, ovako predstavljen Kurosavin filmski narativni klaster s jedne strane zadržava osnovnu premisu priče $U$ čestaru, dok je na drugoj strani delimično izneverava. Umesto na sedam iskaza/izjava/priznanja/ispovesti/priče, filmski narativ baziran je na četiri podjednako uverljiva, odnosno podjednako neuverljiva pripovedača koji iznose četiri protivrečne verzije istog događaja. Tako se pokazalo da sve četiri verzije istine zavise od ugla gledanja i subjektivnih namera svakog od učesnika. Narativi 
priče nam pokazuju da se od troje protagonista upletenih u narativ sa fatalnim ishodom ispostavlja da je Tađomaru brutalni kriminalac, Masago nevina žrtva, a Takehiro ponosni ratnik. Sve to se čini kao istina dok se ne oglasi drvoseča sa pričom o onome što je video iz prikrajka. Međutim, čak se i navodno nepristrasnoj drvosečinoj priči nazire mogućnost izvrtanja istine. Dok se drvosečin iskaz bazira na stereotipu o ženinoj površnosti i lakomosti, razbojnikovoj umišljenoj hrabrosti i muževljevom kukavičluku, njegova verzija događaja istovremeno skriva udeo u zločinu, sve dok građanin to ne iznese u sferu javnog odbacujući potrebu za istinom.

Akutagava je ovim narativnim draguljem očito želeo da ukaže kako stvarnost ili istina ne postoje nezavisno od ljudske svesti i subjektivnog osećaja stvarnosti, identiteta i opažaja, sugerišući da je svaki od sedam priča, paradoksalno, istovremeno istinito i neistinito. Pa ipak, za razliku od Akutagave, Kurosava ovu moralnu priču prikazanu kao epistemološki košmar okončava otvorenog kraja u pozitivnoj atmosferi sa idealom dobrote. Napušteno novorođenče pronađeno $u$ oronulom hramu Rašomon pripisuje se drvoseči koji na sebe preuzima starateljstvo i tim činom iskupljuje ideju o ljudskoj dobroti nasuprot hipotezi o sveopštem zlu. Premda priča i film implicitno istražuju nemogućnost obnavljanja i iskupljenja, glavna tema o otkrivanju istine kao razlici između dobra $\mathrm{i}$ zla proistekla iz ponavljanja dva suprotstavljena principa i njihovog neprestanog prožimanja podržana je jednostavnim gestovima dobrote i požrtvovanja. Dosledan zaključak u formi razlomljene kaleidoskopske strukture sučeljenih narativnih perspektiva, $\mathrm{u}$ kojoj se pokazuje ambivalentna priroda istine, čime je Akutagava želeo da istakne da istina može biti drugačija iz perspektive druge osobe.

Zamišljen kao preplitanje suprotstavljenih gledišta u flešbek maniru, uokviren kamerom koja snima pod kišnim osvetljenjem, ,jedan od najvećih sineasta kišse" (Delez 220) zaplet filma Rašomon uvodi u raspoloženje napetosti i drame prateći glavnu ravan priče $U$ čestaru koja propituje (ne)pouzdanost perspektivâ pripovednog teksta. Iskrenost likova i njihovi opisi događaja postaju lažni. Dokazi se potkrepljuju činjenicama, ali se odmah dovode u pitanje. Svih sedam iskaza unutar Akutagavine priče (drvoseče ispitanog u redarstvu; putujućeg monaha ispitanog u redarstvu; izjava redarstvenika: bivšeg prestupnika; izjava starice ispitane u redarstvu; priznanje tađamarua; ispovest žene u hramu Kijomizu; priča duha umrlog kroz usta medijuma), kao i četiri svedočanstva u Kurosavinom filmu, odlikuje jedinstven stil koji odgovara karakteru, emocionalnoj investiranosti, tonu i leksici onoga ko pripoveda, dok se osobenost filma prepoznaje se brojnim složenim snimcima u pokretu, zahvaljujući ritmičnoj montaži i tematski značajnoj dubinskoj 
kompoziciji kadra. Gledanjem filma stiče se utisak da se kamera neprekidno kreće, neretko silovito i žustro, dok stvarnost sa stanovišta pojedinačnih pripovedača Kurosava prikazuje subjektivnim kadrovima. Nepodudaranje ispreplitanih priča koje pričaju odmetnik Tađomaru, Makago (Takehirova supruga), samuraj Takehiro - Makagin suprug (posredstvom medijuma), a potom i drvoseča, usložnjavaju već dovoljno komplikovanu sliku. Kraće rečeno, diskursom narotologije i teorije proze, svi pripovedači u Akutagavinoj priči su nepouzdani (v. But 167-186), ,jer nastaje iz pričanja ili pisanja nekoga ko se obraća sebi (ili drugom - prim. B.Ž.). To je uslov diskursa u kome, kako znamo, mogućnost govorenja istine stvara mogućnost pogrešnog razumevanja, pogrešnog opažanja i laganja“ (Martin 131). Samim tim i kamera Kurosavinog filma se čini nepouzdanim pripovedačem, a sa njim i njegov gledalac kojeg ostavlja bez razrešenja, baš poput Akutagavine priče koja okončava narativnim segmentom u kojem se oglašava duh ubijenog samuraja. Karakteri ili prirode iskaza, kao i demografska kategorija, profesija fokalizatora i fokusi likova (onog ko govori) takođe mogu da budu važni psihološki, motivacijski pokretači i faktori koji bitno određuju verodostojnost ispričanog. Dok se jedna grupa - svedoci - oglašava iskazom (drvoseča; monah) ili izjavama (redarstvenik - bivši prestupnik; starica - majka napastvovane žena) pred redarstvom (organi zakona), druga grupa, koju čine akteri događaja i jedini imaju imena, oglašava se priznanjem (Tađomarurazbojnik), ispovešću (Masago, Takehirova supruga, 19. godina), odnosno pričom (samuraj-duh Takehira, 26. godina), koji artikulišu nijansiranost u pogledu upotrebe retoričkih sredstava i tonom iskaza.

Slično Rjunosukeu Akutagavi, Džulijan Barns siže svog romana Troje, postavljenog u savremeni kontekst, ne nalazi u modernom, nego u tradicionalnom korpusu. Star koliko književnost, opis romana može se svedeno ilustrovati kao ljubavni trougao između dvojice prijatelja i jedne žene - supruge, najpre jednog, a potom drugog prijatelja. U seriji različitih mikronarativa, katalizatora ili satelita glavnog narativa, veštom upotrebom opštih mesta i klišea, premrežavanjem intertekstualnih relacija, kulturološkim aluzijama, citatima, pripovedni interes se usmerava prema psihološkom prikazu likova. Koristeći se socijalnim tipovima, pomeranjem perspektive, inverzijom i humornom ironijom, Barns karikira kolektivne mitove, poigrava se stereotipima, odnosno razlikama u životnim stilovima i shvatanjima unutar evropskog (britanski i francuski) i američkog načina života. 
Roman Troje podeljen je na sedamnaest numerizovanih narativnih segmenata, kao dominantnom jedinicom teksta, koji naslovom nastoje da tematski determinišu i sažmu fabularno tkivo teksta koje im predstoji. Pojedina zasebna poglavlja mogu se čitati kao zasebne priče, svojevrsni short story cycle, koje, međutim, izvan romaneskne strukture ne bi bile održive. Jednom pričom ispričanom kroz više manjih narativnih rukavaca različitih dužina $u$ okviru pojedinačnih poglavlja Barns se još jednom predstavio kao autor za koga je poigravanje strukturom romana $i$ ispitivanje njegovih granica od krucijalnog značaja prilikom organizovanja narativne građe. U slučaju romana Troje autor je pokušao da istovremeno, na metanivou, problematizuje odnos junaka i čitaoca izostavljajući jednu, pripovedačku instancu, uvođenjem tri centralna lika okupljena oko drevne premise: ljubavnog trougla između jedne junakinje (Džilijan) i dva prijatelja (Stjuart i Oliver), usložnjavanjem odnosa, perspektiva i njihovog međusobnog preplitanja u ovoj melodramskoj rašomonijadi. Delo tako zadobija oblik dramskog teksta ili filmskog scenarija, budući da sva tri lika govore u prvom licu jednine. Ovim postupkom izbegnuta je intervencija naratora, da približava ili objašnjava radnju, a sa tim i rizik da ugrozi pretpostavljenu objektivnost prikazivanja nultom fokalizacijom (v. Ženet Tipovi; Perspektive; Prins 2011) na koju pretenduje pripovedni postupak romana. Pitajući se da li roman uopšte može da ima tradicionalno shvaćenog i određenog pripovedača, romanom Troje Džulijan Barns suvereno nudi odričan odgovor, stvarajući utisak usmenog, neposredovanog proznog pripovedanja kakvo baštini i Rjunosuke Agutagava u priči $U$ čestaru.

Osnovna priča romana Troje razvija se kroz manje narativne celine, gde se u okvirnom toponimu (najpre Engleska, potom Francuska i Amerika) oglašavaju likovi $\mathrm{u}$ istovetnoj narativnoj formi. Pripovedanje je raslojeno na višestruku unutrašnju fokalizaciju (v. Ženet Tipovi; Perspektive; Prins 2011) kojoj je dodeljeno prvo lice pripovedanja sa naizgled proizvoljno organizovanim redosledom pojavljivanja junaka. Likovi se smenjuju u relativno pravilnom ritmu, što bitno određuje dinamiku pripovedanja, jezik, ton i tematske krugove u sadržaju glavne priče. Osim prezenta koji, zapravo, čini vreme pripovedanja, prisutan je i perfekt, najčešće putem evociranja i prisećanja, koji nagoveštava ili odlaže da ispriča priču, te na taj način usporava pripovedanje o onome što je u vezi sa osnovnom pričom, određenim događajem, epizodom ili situacijom koja je usledila. Središnja pripovedačka svest fragmentizovana je na glasove troje protagonista čiji se izolovani uglovi posmatranja, kako priča odmiče, međusobno prepliću, ukrštaju, podudaraju, nadopunjuju, polemišu, direktno ili indirektno suprotstavljaju u svesti čitaoca/recipijenta. U nekoliko slučajeva narativni segmenti protagonista dopunjeni 
su pripovedanjem sporednih likova u funkciji posmatrača/svedoka (Madam Vajat Džilijanina majka; gospođa Dajer - stanodavka; Mišel - prodavačica u cvećari i jedini nepristrasni sporedni lik; Val - Oliverova bivša devojka; Gordon Vajat bivšeg supruga i oca Džilijan), čije intervencije u tekstu ipak ne destabilizuju naoko već tendenciozno nestabilnu strukturu romana.

Pripovedanje tako poznaje tri para glavnih tokova koji određuju vremensku trasu pripovedanja romana ostvarenu između protagonista: Stjuart i Oliver, Stjuart i Džilijan, Oliver i Džilijan, odnosno težištu koje se premešta na svakog junaka u ovim relacijama, kao i tački gledišta onog trećeg koji sa strane može da ponudi nešto izmešteniji, objektivniji uvid pomenutih relacija, kao i u ponašanju njihovih učesnika: „Objektivnost prikaza koja se postiže tehnikom navođenja dijaloga od strane junaka u okviru njihovih narativnih segmenata stoga je samo prividna, i otvara nove mogućnosti subjektivizacije zajedničkog iskustva od strane svakog junaka ponaosob“ (Ivanović 215). U ovom trouglu nazire se zaplet i melodramatična završnica čitavog romana koja može imati nekoliko ishoda. O tome, najzad, nagoveštavaju i naslovi određenih poglavlja (,Svaki, svaka, svako“, „Bio sam sjajan tog leta“, „Ne volim te“, „Ne znam da li da verujem u to“, „S ljubavlju itd.“, „Sada je u pepeljari samo jedna cigareta“). Ako su nakon poslovičnog predstavljanja u prvim poglavljima predmet narativa bili Stjuart i Oliver, prijatelji iz srednjoškolskih dana, sasvim je opravdano što se Džilijan uvodi sa zakašnjenjem. Postupnim nagoveštajima u pričama protagonista uvode se drugi protagonisti čiji poredak pojavljivanja neprestano pomera čitalački horizont očekivanja, budući da redosled pojavljivanja junaka utiče na tok daljeg pripovedanja koje treba da dovede do razrešenja. Kako se pripovedanje razvija, prostor se menja, a sa tim i okvir pripovedanja. Akcenat se pomera sa jednog na drugi par protagonista i njihov odnos na drugi par junaka i njihov odnos, ne napuštajući pritom nijednog trenutka indirektan/pasivan kontakt sa trećim glasom koji čak i kada je odsutan/odsutna iz ukrštenih pripovednih segmenata na formalnom planu, nije sasvim isključen/a na planu sadržaja, i obratno.

Narativna forma romana Troje propituje se, dakle, najpre sa stanovišta strukture, da jedinica teksta nisu poglavlja (što je neretko svojstveno romanu, ukoliko je podeljen na manje logičke, (a)hronološke i/ili uže tematskomotivske delove), nego narativni segmenti koji predstavljaju po jednu sekvencu pripovedanja sva tri junaka u jednom određenom trenutku. Zbog toga tekst romana nalikuje filmskom scenariju sastvaljenom od niza kraćih i dužih pripovednih celina, kojoj prethodi ime junaka koji izgovara segment narečenog poglavlja. Pored glasova protagonista, pripovedne deonice u romanu pripadaju i pomenutim 
sporednim likovima u neposrednoj vezi sa jednim od tri junaka, koji u vidu svedočenja dodatno proširuju ugao posmatranja novim pripovednim slojem nedelatni i nedramatizovani pripovedači (V. But 167-186). Na taj način ponuđen je drugačiji uvid i ugao posmatranja iz kojeg se uvedeni likovi oglašavaju u vezi sa dominantnim tematskim ili motivskim sadržajem narativa koji postaje predmet određene narativne epizode.

Tri glavna narativna toka uz povremene uplive sporednih/epizodnih glasova dodatno usložnjavaju perspektivu, dopunjavajući onu koju pružaju njeni pripovedači-protagonisti. Njihovo pripovedanje podseća na neposredno obraćanje čitaocu kao vrhovnom arbitru i svedoku u konstituisanju priče koja nastoji da se složi u čitaočevoj svesti tokom i nakon nazmeničnih iskaza protagonista. Zahvaljući promenama u pripovedanju, prelaskom sa monološkog na dijaloški oblik, čitalac svedoči različitim iskazima kao verzijama istine. Njena relativnost posredovana je činjenicama koje su praćene komunikacijskim šumovima (psihološke, semantičke i mehaničke smetnje) u procesu saopštavanja o određenim događajima i situacijama koja se tiču troje protagonista. Zahvaljujući monološkoj formi koja podseća na dramsko izvođenje i data je u neposrednom, ispovednom obliku, često serijom retoričkih pitanja usmerenih prema pretpostvljenom recipijentu, hipotetički objektiv se premešta na govorna lica koja ne mogu da čuju iskaze svojih prijatelja, premda upoznati sa njihovim karakterom i naravi mogu da anticipiraju njihove odgovore. $U$ obraćanju svojstvenom živoj reči, govoru tj. usmenom pripovedanju, instanca čitaoca ispostavlja se kao nemi slušalac kojem se svi junaci pojedinačno obraćaju čineći ih aktivnim učesnicima priče. Okolnost sa kojom se suočava aktivni slušalac simulira svakodnevne životne situacije kada „mnoštvo različitih verzija istog događaja ne izgledaju kao isti“ (Ivanović 213). Kako je forma obraćanja data u pluralu, zamenica Vi/vi, Vama/vama je ambivalentna, jer osim što može da se tumači kao znak uvažavanja, u uslovima anonimnih i učtivih situacija uslovljenih socijalnim kontekstom i manirom, može istovremeno da upućuje na neimenovano mnoštvo auditorijuma pred kojim se ova melodrama odvija. „Način na koji deluju narativni segmenti ima za cilj uspostavljanje odnosa sa slušaocem koji će nastaviti da se razvija tokom romana paralelno sa razvijanjem međusobnih odnosa junaka“ (Ivanović 197).

Savršeni ili implicitni čitalac prema kome je organizovan i usmeren pripovedni tok može da ima bar dve pozicije ili dva statusa koje ga određuju u njegovom daljem pozicioniranju priče. U prvom slučaju pomenuti čitalac može biti autor, koji prema beleženju ili uz pomoć diktafona vrši transkripciju iskaza pomoću kojih formira i raspoređuje pripovednu građu. U drugom slučaju, pripovedanje ne 
poznaje svog recipijenta, s obzirom da u ovom slučaju njega čini mnoštvo recipijenata sa druge strane teksta, u gledalištu ili iza objektiva kamere dok pomera svoj fokus prema junacima koji se utvrđenom dinamikom i ritmom u režiji više instance smenjuju. S obzirom da dijalog podrazumeva barem dve strane u kojoj se odvija komunikacija, u romanu nema razmene među učesnicima jer komunikacija teče u jednom smeru. Povratna reakcija očitava se u iskazima samih protagonista, koji ironično senče neverbalni gest recipijenta, anticipiraju reakciju sluša/oca/laca nakon pripovedne deonice u kojoj se projektuje osuda, afirmacija ili moralni korektiv junakovog iskaza i postupka kroz anticipiranje ili prepričavanje onog što su drugi junaci rekli/govorili ili učinili u određenoj situaciji (postupkom glasine, denunciranja u smeru sticanja čitaočeovog poverenja ili simpatije), čime se vrši udaljavanje od autentičnog, posredovanog pripovedanja iz prve ruke. Zahvaljujući ovakvoj strategiji pripovedanja, recipijent nema samo neposredan odnos sa pripovednim sadržajem, već i sa karakterom junaka, njegovom emotivnoemocionalnom investiranošću, elokvencijom, dopadljivošću ili antipatiji u obraćanju i delanju, odnosno suspenziji izrečenog i učijenog od strane samog protagoniste. Ispovest protagonista, dakle, počiva na poverenju koje nije moguće između troje učesnika, budući da su, na metanivou, oni povod pripovedanja svakog junaka ponaosob. Zbog toga je neophodno stvoriti privid objektivističke distance čiji je nosilac usputni nepoznati sagovornik sklonjen iza teksta. Implicitni čitalac priziva se kao kohezivno sredstvo pripovedanja romana u kojem pohranjeni narativ nastavlja da živi sopstvenu istinu i trajanje, u onoj meri u kojoj tekst može da se primeni na realne okolnosti u svakodnevnim životnim situacijama.

Više različitih pripovedača suočava čitaoca/recipijenta sa sumom različitih segmenata istog sadržaja koje treba povezati u konzistentnu celinu, uzimajući u obzir snalaženje na vremenskom planu i različite načine prikazivanja, premda se u okviru segmenata, u kojima se iznose pojedinačna viđenja određenih događaja iz bliže i dalje prošlosti junaka-pripovedača, upotrebljavaju različita pripovedna sredstva. Objektivnost prikaza koja se postiže navođenjem dijaloga u okviru pripovednih tehnika samo je prividna i otvara mogućnost subjektivizacije zajedničkog iskustva svakog od troje protagonista romana. Drugo pripovedno sredstvo je junakovo prepričavanje onog što je čuo od drugih junaka - pripovedanje iz druge ruke. Zbog toga će se inverzija ispostaviti kao nezaobilazna i važna figura na planu osnovne priče, najpre na nivou karakterizacije junaka, a potom i na ravni međusobnih odnosa: paralelizam i inverzija narativne strukture - na početku, odnosno kraju romana - i promena težišta: kada prijateljstvo prelazi u ljubav, a ljubavna bliskost $\mathrm{u}$ razdvajanje, $\mathrm{s}$ jedne strane; kada prijateljstvo prelazi $\mathrm{u}$ 
antagonizam i alijenaciju, a poverenje $\mathrm{u}$ nepoverenje, $\mathrm{s}$ duge strane; kada posmatrači-učesnici (promenom geografskog okruženja seljenjem iz Engleske u Francusku) postanu objekti posmatranja i komentara od strane drugih, sporednih posmatrača-učesnika njihovih postupaka, slučajnih, epizodnih pripovedača. Ukoliko ljubav predstavlja širu, a preljuba užu temu romana Troje, ono što će se pokazati konstantnim i nepromenljivim jesu ljudske strasti i naravi, što će svoju konačnicu imati devet godina kasnije u romanu Ljubav, itd. $(2000)^{3}$.

Relativizacija istine kroz prikaz mnoštva pojedinačnih istina, istorijâ i mišljenja, njene verzije i varijacije, ono je što se nalazi u srži Barnsovog romanesknog stvaralaštva. U nameri da pokaže da je istina uvek subjektivna kategorija i da zavisi isključivo od pozicije posmatrača, Barns je još jednom nastojao da ispita kako se perspektive $\mathrm{u}$ romanu menjaju prema ulogama $\mathrm{u}$ stvarnom životu. Na relativnost istine Barns će ukazati aforistički, ruskom izrekom pozajmljenom za svrhu mota romana: „Laže kao očevidac“. Ovom dosetkom sugeriše se da je perspektiva drugog, ma koliko ona težila objektivnom i nepristrasnom, uvek posredovana pozicijom i drugim spoljašnjim i unutrašnjim faktorima posmatrača koji mogu uticati na rasuđivanje u prikazivanju izvesnog događaja i mogu se bitno razlikovati od doživljaja iz neposrednog iskustva samog učesnika događaja. Roman Troje implicira stanovište o nepostojanju jedne verzije događaja, odnosno viđenja događaja, jer je svaki događaj subjektivno određen i obojen: „Svaki od likova koji govori o događajima iz sopstvenog života jeste očevidac i učesnik, prisutan u ličnoj istoriji o kojoj je reč, umešan u događaje i shodno tome pristrasan“ (Ivanović 215). Drugačije rečeno, iskazi naglašeno subjektivnog i pristrasnog sagovornika destabilizuje istinu. Svojim narativnim postupkom Barnsov roman nam sugeriše da ukoliko svedoci svedoče, onda i čitalac svedoči. Dakle, ili svi govore istinu, ili svi lažu, jer ima onoliko istina koliko ima njenih učesnika ili svedoka.

U priči $U$ čestaru i romanu Troje narativ figurira kao dijaloška forma, budući da bez recipijenta nema komunikacije, čak iako je primalac poruke imaginaran čitalac ili nemi slušalac. Utisak monologa u obraćanju, ispovedanja, odnosno živog, usmenog govora, kao i emocionalno senčenje iskaza, izbegnuti su u korist samih junaka, budući da nema posredovanja priče od strane pripovedača kao autora teksta. Tako dobijen narativ pretenduje na autentičnost ispripovedanog, lišen manipulativnih pripovednih intervencija, strategija, odnosno postupaka, čime je ostavren efekat neposredne komunikacije. Izuzimanjem funkcije pripovedača radi

\footnotetext{
${ }^{3}$ Srpsko izadnje romana Ljubav itd. Džulijana Barnsa biće objavljeno tek 2011. godine.
} 
približavanja usmenom obliku proznog pripovedanja i uvođenjem čitaoca/recipijenta kao tehničkog, odnosno narativnog i kompozicionog sredstva, posrednika ali i činioca pripovedanja, Akutagava i Barns stvaraju utisak autentičnog i neposredno ispripovedanog kretanjem između pojedinačnog i univerzalnog. Suspendovanjem pripovedača ukinuta je distanca između pisca i čitaoca književnog dela, dok je priča oslobođena posredovanja između učesnika i recipijenta, a sa tim i fiktivnog, unutrašnjeg glasa koji posreduje na relaciji teksta i onih koji taj tekst samo pasivno primaju, čineći ih tako ne samo njenim svedocima, nego i saučesnicima. Međutim, ukoliko za slušaoca uzmemo autora koji vodi dijalog, komunicira sa svojim junacima, neće biti bitnih promena u tradicionalnom odnosu likova i čitaoca. Ukidanjem ili smanjivanjem distance u ovoj relaciji, smanjuje se fiktivna distanca između junaka $i$ autora, što nesumnjivo utiče na mogućnost/verovatnoću njihove fiktivnosti, odnosno njihove realističnosti i uverljivosti.

I kod Akutagave i kod Barnsa problem istine podseća nas na uvek aktualno pitanje sa kojim se gotovo svakodnevno suočavamo. Zahvaljujući verzijama istog događaja čini se da jedan događaj ne izgleda isto. Najčešći razlog je stepen razvijenosti perceptivnog aparata, moralnih skrupula, nepouzdanosti pamćenja i selektivnosti sećanja, a sa tim u vezi i sposobnosti interpretiranja i tumačenja onoga koji svedoči. Posredi je tako svojevrsno ponavljanje koje, delezovskim jezikom rečeno, proizvodi razliku (v. Delez 2009). Višestruka perspektiva prikazivanja jednog događaja u slučaju Agutagavine priče $U$ čestaru, ili više različitih događaja i situacija u slučaju Barnsovog romana Troje - u oba narativa je doveo do poigravanja sa strukturom pripovedanja i klasično/tradicionalno shvaćenom funkcijom pripovedača. Izuzimanjem jednog centralnog a uvođenjem tri glavna homodijegetička/autodijegetička pripovedača (uz nekoliko sporednih glasova) kao nosilaca perspektivâ i informacijâ neophodnih za saznavanje istine o događajima i situacijama, Rjunosuke Akutagava i Džulijan Barns ističu pluralizam istine, mogućnost njene povrede i pogrešivosti unutar fikcije, koja se prenosi u svest čitalaca. Istovremeno, posezanje za ovakvim pripovednim rešenjem može da se razume i kao nepoverenje obojice autora prema pripovedačkoj instanci i njenim zahtevima. 
Branislav Živanović

MULTIPLE FOCALIZATION IN RYŪNOSUKE AKUTAGAWA'S “IN A GROVE” AND JULIAN BARNES' TALKING IT OVER

\section{Summary}

In this paper, we will deal with narrative procedures and analysis of multiple conflicting perspectives from which the events and situations are presented in the strory "In a Grove" of the Japanese writer Ryūnosuke Akutagawa and the novel Talking It Over by the British writer Julian Barnes. As in the work of both authors the narrative process is conditioned by focal points, the methodological framework of the paper is based on the Gérard Genette's narratological approach and theoretical works on perspective and focalizations. Since Genette specifies the place of the focalizer within the story/diogese by insisting on distinguishing the seer from the speaker, we will show that instead of a classically/traditionally determined central narrative voice, the degree of reliability and truthfulness of narration in Akutagawa's and Barnes' narrative depends on the perspective of several characters as central voices who are at the same time the bearers of action and narration.

Key words: focalization, perspective, Akutagawa, Barnes, storytelling, narrator, story, narative 


\section{LITERATURA}

Abot, H. Porter. Uvod u teoriju proze. Prev. s engleskog Milena Vladić, Beograd: Službeni glasnik, 2009.

Akutagava, Rjunosuke. Rašomon i druge priče. Prev. s japanskog Danijela Vasić i Dalibor Kličković, Beograd: Rad, 2008.

Barns, Džulijan. Troje. Prev. s engleskog Ivana Đurić Paunović, Beograd: Geopoetika, 2011.

Barthes, Roland. „Uvod u strukturalnu analizu pripovjednih tekstova”. Prev. s francuskog Dubravka Celebrini, Republika, br. 7-8, 1983.

But, Vejn. Retorika proze. Prev. s engleskog Branko Vučićević, Beograd: Nolit, 1976.

Delez, Žil. Pokretne slike. Prev. s francuskog Slobodan Prošić, Novi Sad: Izdavačka knjižarnica Zorana Stojanovića, 1998.

Delez, Žil. Razlika i ponavljanje. Prev. S francuskog Ivan Milenković, Beograd:

Fedon, 2009.

Marković, Ljiljana. „Baština narodne mudrosti kao snaga književnosg stvaralaštva u modernizaciji“. Zbornik radova O Petru Kočiću, ur. prof. dr. Aleksandra Vraneš, Višegrad, Andrićev institut, 2017, str. 115-130.

Martin, Volas. Nove teorije pripovedanja. Prev. s engleskog Milena Vladić Jovanov, Beograd: Službeni glasnik, 2016.

Ивановић, Нина. Границе и преплитања: Проблематика жанра у романима Цулијана Барнса. Нови Сад: Матица српска, 2006.

Kođiki - zapisi o drevnim događajima. Prev. sa starojapanskog Hiroši JamasakiVukelić, Danijela Vasić, Dalibor Kličković, Divna Glumac, Beograd: Rad, 2008.

O'Connor, P. J. Recommended: Ryunossuke Akutagava. The English Journal, Vol. 75, No. 7, 1986.

Prins, Džerald. „Nulta fokalizacija“, „Višestruka unutrašnja fokalizacija“. Naratološki rečnik. Prev. s engleskog Brana Miladinov, Beograd: Službeni glasnik, 2011.

Vasić, Danijela. „Različiti tipovi diskursa u začetniku japanskog narativnog žanra monogatari“. Jezik, književnost, diskurs: književna istraživanja: zbornik radova, ur. Prof. dr Bojana Dimitrijević, Filozofski fakultet, Niš, 2015, str. 93-105.

Ženet, Žerar. „Perspektiva i fokalizacija“. Prev. s francuskog Milica Vinaver, Reč, br. 8, april, 1995, str. 83-86. 
Ženet, Žerar. „Tipovi fokalizacije i njihova postojanost“. Prev. S francuskog Dubravka Celebrini, Suvremena teorija pripovijedanja, ur. Vladimir Biti, Globus, Zagreb, 1992, str. 96-115. 
